\title{
Interfaith Dialogue and Löhe Memorial Library
}

by Trevor Schaefer

The proposition at the heart

of monotheism is not what it has often been taken to be: one God, therefore one path to salvation. To the contrary, it is that unity is worshipped in diversity. The glory of the created world is its astonishing multiplicity: the thousands of different

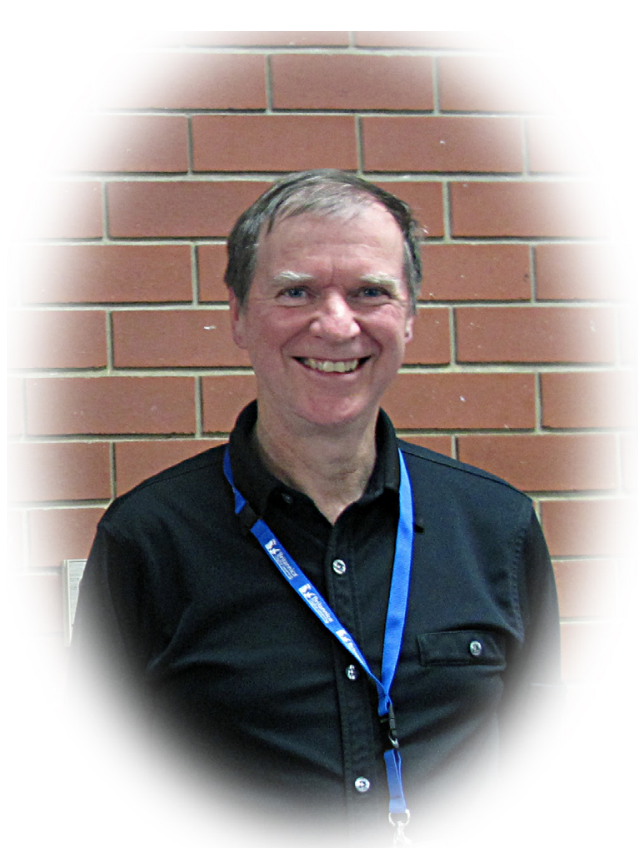
languages spoken by mankind, the proliferation of cultures, the sheer variety of the imaginative expressions of the human spirit, in most of which, if we listen carefully, we will hear the voice of wisdom telling us something we need to know. That is what I mean by the dignity of difference. ${ }^{1}$

have been an employee of the Australian Lutheran College, at Löhe Memorial Library, for 15 years and a member of the Council of Christians \& Jews for nearly 10 years, the last four as Secretary of the SA Chapter.

1 Jonathan Sacks, The dignity of difference : how to avoid the clash of civilizations (London: Continuum, 2002), 20. 


\section{"Luther is better}

\section{known as a}

polemicist than as a

dialogue partner. In

the area of Jewish-

Christian dialogue, he is best known for

the document he

wrote as a grumpy

old man, On the

Jews and their Lies.

This publication has

been condemned

by contemporary

Lutherans, including the Lutheran Church of Australia."
My interest in the dialogue between Christians and Jews has been nurtured by a number of factors:

Visits to Israel during my travels overseas after university study;

Study of the Hebrew language at Luther Seminary; and

Interest in the history of the Holocaust in Europe, 1933-1945.

Working in a library has enhanced and deepened these interests. A library, by its very nature, is ecumenical, because in order to support research in a particular area, the collection needs to be representative of the wide range of studies and opinions available.

The collection of Löhe Memorial Library is an excellent example of this ecumenicity. One of the strengths of the collection is Biblical Studies: Old Testament, or Hebrew Scriptures, and New Testament. As well, we have an extensive collection of Jewish literature from the period between the Testaments, including the Dead Sea Scrolls. There are also numerous editions of the Talmud in Hebrew and English translation.

Just a few bays down are even more numerous editions of the works of Martin Luther, in German, Latin and English translation. Luther is better known as a polemicist than as a dialogue partner. In the area of Jewish-Christian dialogue, he is best known for the document he wrote as a grumpy old man, On the Jerws and their Lies. This publication has been condemned by contemporary Lutherans, including the Lutheran Church of Australia. ${ }^{2}$

But long before he wrote this ugly piece, he attempted to dialogue with a treatise called, That Jesus Christ was born a Jew.

If the apostles, who were also Jews, had dealt with us Gentiles as we Gentiles deal with the Jews, there would never have been a Christian among the Gentiles. Since they dealt with us in such a brotherly fashion, we in our turn ought to treat the Jews in a brotherly manner in order that we might convert some of them. ${ }^{3}$

We may not agree with his motive for dialogue, but at least he attempted it.

The Council of Christians and Jews is an organisation which has been fostering dialogue between Christians and Jews since the Second World War. It is an international organisation and chapters have been formed in a number of Australian states since the 1980s. We meet on a regular basis to discuss various aspects of our traditions and to promote understanding and dialogue between the faiths. ${ }^{4}$

The rediscovery of the Jewishness of Jesus has been one of the areas where theology has greatly benefitted from this dialogue. Jesus of Nazareth was an observant Jew who began his teaching ministry in his local synagogue, reading from the Torah scroll. He mixed largely with other Jews and attended the prescribed festivals in the

2 "Lutherans and Jews: A Statement by the Council of Presidents of the LCA," Gesher 1 no.6, (1997): 14.

3 Martin Luther, 1523, "That Jesus Christ was Born a Jew," in Luther's Works, vol. 45, ed. Walther Brandt, (Philadelphia: Muhlenberg Press, 1962), 200.

4 http://ccj.org.au/ 
"We also regularly have public meetings where we examine biblical texts from a Jewish and

Christian viewpoint, for although we share Scriptures in common, we do not interpret them the same way." temple in Jerusalem. The first Christians were all Jews who continued to observe the Jewish laws, while recognizing Jesus as the promised Messiah, the Christ. The break between church and synagogue came long after his life and death and resurrection.

One goal of the SA Chapter is to raise the awareness of churchgoers about modern Judaism. This is important, so that modern Christians do not view Jews through stereotypes derived from 2000 years ago. We also regularly have public meetings where we examine biblical texts from a Jewish and Christian viewpoint, for although we share Scriptures in common, we do not interpret them the same way. ${ }^{5}$

Finally, I would like to say what a pleasure it has been to become friends with Jews here in Adelaide, and to attend services at Beit Shalom Synagogue. This is known as "the singing schule", and if you attend a Shabbat service, you will find out why. The enjoyment of the Sabbath that they share, and the reverence they show for the Torah, are a blessing to the Lord and to anyone who is present.

Thank you.

\section{Bibliography}

Luther, Martin. “1523. That Jesus Christ was Born a Jew.”In Luther's Works, vol. 45, edited by Walther Brandt, 200. Philadelphia: Muhlenberg Press, 1962.

Lutherans and Jews: A Statement by the Council of Presidents of the LCA, 1997. Gesher (Bridge) 1, no. 6, 14.

Morgan, Rabbi Fred. Divided by a Common Scripture: How Jewish Tradition Reads the Bible. Werribee, Vic.: Werribee Chapter, Council of Christians and Jews, 2001.

Sacks, Jonathan. The Dignity of Difference: How to Avoid the Clash of Civilizations. London: Continuum, 2002. 